\title{
Elite formation in the higher education systems of Ireland and the UK: Measuring, comparing and decomposing longitudinal patterns of cabinet members.
}

\author{
Sharon Feeney \\ Technological University Dublin, sharon.feeney@tudublin.ie \\ John Hogan \\ Technological University Dublin, john.hogan@tudublin.ie \\ Brendan O'Rourke \\ Technological University Dublin, brendan.orourke@tudublin.ie
}

Follow this and additional works at: https://arrow.tudublin.ie/buschmarart

Part of the Business Commons, and the Social and Behavioral Sciences Commons

\section{Recommended Citation}

Feeney, Sharon; Hogan, John; and O'Rourke, Brendan, "Elite formation in the higher education systems of Ireland and the UK: Measuring, comparing and decomposing longitudinal patterns of cabinet members." (2017). Articles. 140.

https://arrow.tudublin.ie/buschmarart/140

This Article is brought to you for free and open access by the School of Marketing at ARROW@TU Dublin. It has been accepted for inclusion in Articles by an authorized administrator of ARROW@TU Dublin. For more information, please contact arrow.admin@tudublin.ie, aisling.coyne@tudublin.ie,gerard.connolly@tudublin.ie.

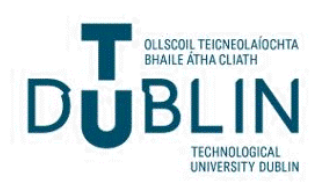


Dublin Institute of Technology

ARROW@DIT

2017

Elite formation in the higher education systems of Ireland and the UK: Measuring, comparing and decomposing longitudinal patterns of cabinet members.

Sharon Feeney

John Hogan

Brendan O'Rourke

Follow this and additional works at: http://arrow.dit.ie/buschmarart

Part of the Business Commons, and the Social and Behavioral Sciences Commons

This Article is brought to you for free and open access by the School of Marketing at ARROW@DIT. It has been accepted for inclusion in Articles by an authorized administrator of ARROW@DIT. For more information, please contact yvonne.desmond@dit.ie, arrow.admin@dit.ie,

brian.widdis@dit.ie. 
This is the final submitted version of the paper the published version of which is Feeney, S., Hogan, J. \& O'Rourke, B. K. (2017) Elite formation in the higher education systems of Ireland and the UK: Measuring, comparing and decomposing longitudinal patterns of cabinet members. British Journal of Education Research. Available on early view at: http://onlinelibrary.wiley.com/doi/10.1002/beri.3284/full

\title{
Elite formation in the higher education systems of Ireland and the UK: measuring, comparing and decomposing longitudinal patterns of cabinet \\ members
}

Sharon Feeney, Head of Learning Development, College of Business, Dublin Institute of Technology, Aungier Street, Dublin 2, Ireland, Email: sharon.feeney@dit.ie, Website: www.sharonfeeney.com Ph: $+35314023243$

John Hogan Research Fellow, College of Business, Dublin Institute of Technology, Aungier Street, Dublin 2, Ireland, Email: John.hogan@ dit.ie, Website: www.johnhogan.net, Ph: +35314027137

Brendan K. O'Rourke, Director of the Business, Society and Sustainability Research Centre, , College of Business, Dublin Institute of Technology, Aungier Street, Dublin 2, Ireland, Email: brendan.orourke@dit.ie, Web: www.brendankorourke.com Ph: +35314027097

\begin{abstract}
The role of higher education systems in the formation and reproduction of governing elites, and their countervailing potential for the creation of a more egalitarian, or meritocratic, society has been an enduring subject of concern, debate and research. Many of these debates are made all the more difficult by our inability to directly compare elite formation systems within and between countries and over time. To resolve these problems, this paper employs elite formation quantitative indices to directly and transparently compare elite formation systems, namely the role of higher education systems in political elite formation over three quarters of a century in two countries. Specifically, the paper compares the influence, exclusiveness and eliteness of the Irish and British higher education systems in the production of their respective governing political elites in the 75 years between 1937 and
\end{abstract} 2012 
This is the final submitted version of the paper the published version of which is Feeney, S., Hogan, J. \& O'Rourke, B. K. (2017) Elite formation in the higher education systems of Ireland and the UK: Measuring, comparing and decomposing longitudinal patterns of cabinet members. British Journal of Education Research. Available on early view at: http://onlinelibrary.wiley.com/doi/10.1002/beri.3284/full

\section{Keywords}

Elite, ministers; education; universities; higher education

\section{Introduction}

This paper analyses the role of higher education systems in the formation of two comparable political elites: cabinet ministers in Ireland and the United Kingdom (UK) between 1937 and 2012. Specifically, our study compares the changing influence, exclusiveness and eliteness of the Irish and UK higher education systems in the formation of cabinet ministers. The period is examined as a whole, and in five 15 year increments, to provide detailed insights into our findings across the countries and time.

Using indices developed by O'Rourke, Hogan and Donnelly (2015) we possess the means to quantitatively compare elite formation systems, as well as their constituent parts, synchronically and diachronically. In general, elites play a key role in governance and have been seen to be particularly important in explaining policy when they are sufficiently cohesive to share a particular model, programme, or story (Genieys and Smyrl 2008). Higher education is important in forming the world views of its graduates. A process of socialisation occurs in higher education 'by which persons acquire the knowledge, skills and dispositions that make them more or less effective members of their society' (Weidman et al., 2001, p. 4). The networks graduates participate in, when in higher education, can influence their lives (Podolny and Barron 1997). An appreciation of the level of concentration of elite formation in such institutions is vital to understanding if, and perhaps when, such elites might gain cohesiveness in governance.

This paper begins with an examination of the literature on elites and their formation in higher education. From there we provide background on the higher education systems and the 
This is the final submitted version of the paper the published version of which is Feeney, S., Hogan, J. \& O'Rourke, B. K. (2017) Elite formation in the higher education systems of Ireland and the UK: Measuring, comparing and decomposing longitudinal patterns of cabinet members. British Journal of Education Research. Available on early view at: http://onlinelibrary.wiley.com/doi/10.1002/beri.3284/full

development of the governing elites in both countries. We then explain how we measure elite formation using O’Rourke, Hogan and Donnelly's (2015) approach. Our data and procedures are then presented. Thereafter, we compare how the elite index (and its constituent measures) varies between the higher education systems educating cabinet ministers in both countries, and over time. This constitutes a unique and innovative approach to gaining an insight into how higher education systems, and their constituent higher education institutions, might shape political elites overtime. We finish with a discussion of our results.

\section{Theoretical perspectives on elite formation in $\mathrm{HE}$}

Traditionally, social scientists regarded the elite as people who are so placed within the structure of society that by their decisions they modify the milieu of many others (Mills 1958, 112). Seminal research on elites, looking at societal divisions, elite power and the movement of elite power, include The Ruling Class, a study of the division of societies into a ruling and a ruled class - elite and masses (Mosca 1939); and The Mind and Society, a study of how power moves within the elite social class (Pareto 1935). Following Mosca's and Pareto's formulation of the concept, 'most scholars conceive of political elites composed of individuals who actually exercise an inordinate amount of political power in society' (Bachrach, 1971, p. xx). According to Lasswell and Kaplan (1950) even in democracies a small number exercise great power.

According to Lasswell et al. (1952) the political elite are the power holders of the body politic, who 'possess the flexibility to set the political agenda to which non-elites respond' (Parry, 2005, p.2). The political elites were merely, for Marx and Engels (1906, 15) 'a committee for managing the common affairs of the whole bourgeoisie', part of an almost epiphenomenon that reflected the underlying structure of capitalism. For liberals, 'elite status stems from the control of human, capital, decision making and knowledge resources' 
This is the final submitted version of the paper the published version of which is Feeney, S., Hogan, J. \& O'Rourke, B. K. (2017) Elite formation in the higher education systems of Ireland and the UK: Measuring, comparing and decomposing longitudinal patterns of cabinet members. British Journal of Education Research. Available on early view at: http://onlinelibrary.wiley.com/doi/10.1002/beri.3284/full

(Desmond 2004, 264), and the state and the political elite were often seen as the main source of such unnatural power, rather than merely a reflection of it. Whatever the theory of political elite role or formation, there is little doubt that being a cabinet minister qualifies one as a member of the political elite (Axelrod, 2015; Riddle, Gruhun and Carolan, 2011). To be a cabinet minister in a democracy, a position of high office, places one in an exclusive club that few members of society will ever be a part of, and a club which plays an exceptionally influential part in political affairs (James, 1999; Marsh, Richards and Smith 2000; Parry, 1967, p. 12).

In addition to regional and national political elites (Botella et al., 2010), there are elites that transcend national boundaries in a variety of spheres. Cotta (1984) and Verzichelli and Edinger (2005) argue that we are gradually witnessing the emergence of a cohesive supranational political elite within the European Union (EU). This elite tends to be made up of fairly homogenous people from the professional middle classes and those whose occupations lend themselves to political life (Keating \& Cairney, 2006: 43).

Evidence suggests that there remains a strong connection between social class and the ability to become a member of the elite (Hartmann 2009; Higley, Kullberg, and Pakulski 1996; Lane 2011). Since the 1970s, a wide range of sociological empirical research has focused on explaining social determinants of the formation of ruling elites (Vergara, 2013: 33). Scholars have shown that one of the main elements in the formation of elites is provided by social class patterns (Huckfeldt and Kohfeld, 1989; Lane, 2007). But, elites that are more hereditary than meritocratic lose legitimacy based on rare skills and sufficient links with the rest of the society to make decisions on its behalf (Brezis and Crouzet 2006). Key to discerning whether particular elites are meritocratic, based on ability and talent, or hereditary, are comparisons across countries and time of how such elites are formed. 
This is the final submitted version of the paper the published version of which is Feeney, S., Hogan, J. \& O'Rourke, B. K. (2017) Elite formation in the higher education systems of Ireland and the UK: Measuring, comparing and decomposing longitudinal patterns of cabinet members. British Journal of Education Research. Available on early view at: http://onlinelibrary.wiley.com/doi/10.1002/beri.3284/full

Central to understanding the meritocratic, or hereditary, processes in elite formation is the role of the education system. Bourdieu (1996) stressed the self-validating nature of the French grand écoles as key to the elite, and their reproduction. In the United States (US), Carnoy et al. (2013, p.45) found elite universities possess 'largely high-social-class-based student bodies' with 'an inordinately high fraction of their students from private preparatory schools', meaning they are effectively recruiting from the same privileged groups that attended in the past. Thus, the charge is that some institutions provide covert services to certain classes 'by concealing social selection under the guise of technical selection and legitimating the reproductions of the social hierarchies' (Bourdieu and Passeron 1990, p. 153). There is little evidence the relationships exposed by Bourdieu have changed noticeably - that universities would change the arrangements of power and privilege existing in the larger society (Sacks, 2007, p.98). These institutions 'contribute to the intra-generational reproduction of the current dominant group' (Borjesson et al., 2016, p.2). Thus, the education system is being used for the socialisation of 'the (already) chosen', to give legitimacy to those selected to join the elite.

Dye and Zeigler (2006) found that 44 percent of government leaders were educated in a small selection of US universities: Harvard, Yale, the University of Chicago, Stanford, Columbia, MIT, Cornell, Northwestern, Princeton, Johns Hopkins, the University of Pennsylvania, and Dartmouth. Yale, in particular, is noted for providing a string of prominent politicians, with graduates occupying the Oval Office from 1989-2009 and contesting most presidential elections as either presidential, or vice-presidential, candidates since the 1960s (Soares 2007, p. 5). As Goldstein (2004) puts it 'The fundamental and clearest presidential pattern at Yale is the extraordinary power of privilege: the intense web of connections knitting together America's upper classes through family ties, business 
This is the final submitted version of the paper the published version of which is Feeney, S., Hogan, J. \& O'Rourke, B. K. (2017) Elite formation in the higher education systems of Ireland and the UK: Measuring, comparing and decomposing longitudinal patterns of cabinet members. British Journal of Education Research. Available on early view at: http://onlinelibrary.wiley.com/doi/10.1002/beri.3284/full

relationships, philanthropic and civic activities, social and recreational life, and of course, education'.

Yet, higher education offers the possibility of a more meritocratic way of producing elites, given that participation in universities is at least formally decided later in life than primary or secondary school choice (Bond, 2012). There is some evidence that even elite universities may, through participation-widening programs, enable those from relatively disadvantaged schools attain equal academic success as more advantaged entrants (Hoare and Johnston 2011). This paper focuses on marshalling empirical evidence relevant to these issues by examining the role of higher education systems in the formation of the governing elite; and to what extent are those universities few in number and limited in whom they admit? Though particular examples may spring to mind, our research contributes to this debate by providing measures of the nature of the relationship between the political elites and the higher education systems in two counties.

\section{Comparing elite formation systems: the university education of Irish and UK cabinet ministers}

Ireland and the UK were selected for examination based upon the criteria most similar case selection (Gerring 2007). While the UK is a much larger country than Ireland, both countries possess a shared political lineage (Farrell, 1994). Both countries are democracies since the early $20^{\text {th }}$ century, when Ireland gained its independence from the UK. A consequence is that the Irish parliamentary and cabinet system contains similarities to the Westminster model (Gallagher 2009; Lijphart 1999). In the Westminster model, parliament is less a purely legislative body, but more a forum wherein law and issues, often initiated by government can be examined and debated (Gallagher 2009; Richards and Smith 2007). The parliament is 
This is the final submitted version of the paper the published version of which is Feeney, S., Hogan, J. \& O'Rourke, B. K. (2017) Elite formation in the higher education systems of Ireland and the UK: Measuring, comparing and decomposing longitudinal patterns of cabinet members. British Journal of Education Research. Available on early view at: http://onlinelibrary.wiley.com/doi/10.1002/beri.3284/full

dominated by the executive and acts as little more than a rubber stamp for government policy (Heywood, 2015).

As a result of the historical linkage, the development of the elites, and the universities, in Ireland and the UK were intertwined. By the $19^{\text {th }}$ century, the vast majority of the British political, social and intellectual elites received their education at places like Oxford, Cambridge and the other five 'ancient'; universities (Trinity College Dublin, prior to 1921, was one of the ancient universities of the UK) (Anderson 1995, 3). While the British public school system contributed 'a disproportionate number of its members to the controlling institutions and key decision-making groups of the country' (Domhoff 1967, p. 5), with one tenth of the Lords being Old Etonians and those elite schools having a persistent influence on their graduates life choices (Bond, 2012; Sutton Trust, 2012), this pales in comparison to the contribution of Oxbridge (Oxford and Cambridge) over the generations (Wakeford and Wakeford 1974; Wakeling and Savage 2015). Oxford and Cambridge are noted for 'the large number of British elites educated at the two institutions, their particular style of education and their reputational dominance over other universities in Britain' (Bond, 2012, p. 618).

Following independence, Ireland developed its own indigenous elite upon the foundations of a rising mercantile class (Lee 1989). In small countries there is a homogeneity that characterises the elite that can lead to the development of a collective identity (Bourdieu 1989; Fanning 2002). The result has been that the people occupying key positions in business and politics in Ireland are sufficiently few that they know, and can readily access, each other (O'Toole 2009).

In the UK, the 1962 Education Act required all Local Education Authorities to provide tuition fees and maintenance grants to full time higher education students. From the 1960s onwards there was a threefold increase in the number of UK universities, a 
This is the final submitted version of the paper the published version of which is Feeney, S., Hogan, J. \& O'Rourke, B. K. (2017) Elite formation in the higher education systems of Ireland and the UK: Measuring, comparing and decomposing longitudinal patterns of cabinet members. British Journal of Education Research. Available on early view at: http://onlinelibrary.wiley.com/doi/10.1002/beri.3284/full

combination of new institutions and the transformation of polytechnics into universities (Greenaway and Haynes 2003). In 1997, the Labour government published the Dearing Report, following which it introduced means-tested tuition fees and income contingent student loans (Alley and Smith 2004). By 2012, of the UK's 163 universities, 123 in England and Wales were planning on charging at least $£ 6,000$ in fees, with many intending to charge the maximum $£ 9,000$ (Hyde and Hyde 2014). In 2012, almost 2.5 million students attended British universities (Higher Education Statistics Agency 2012).

The second half of the $20^{\text {th }}$ century saw the gradual expansion of the university sector in Ireland, with the better off sections of society paying fees and the less well off receiving state support, along with maintenance grants. Following publication of the White Paper Charting our Education Future (Government of Ireland 1995) from 1996/1997 undergraduate fees were abolished. There are 7 universities and 14 institutes of technology - a division of higher education institutions not unlike the binary divide that existed in the UK up to 1992 (Feeney 2014, 15). Most Irish higher education institutions charge a student contribution, which for 2014-15 reached a maximum of $€ 2,750$ (Citizens Information 2015). By 2012 there were over 163,000 students in Irish universities and institutes of technology (Government of Ireland 2012). This widening of access to higher education in Ireland and the UK raises the prospect that cabinet ministers, along with other key decision makers in society, will come from a wider range of universities, thereby lessening the dominance of places like Oxford and Cambridge.

Much has been written about education and elites in both countries (see Courtois 2012; Dunne, King and Ahrens 2014; Kennedy and Power 2010; Power et al. 2013; O'Rourke, Hogan, and Donnelly 2015; Van Zanten and Ball 2015), though this work has often focussed on the post-primary systems rather than higher education systems. The public 
This is the final submitted version of the paper the published version of which is Feeney, S., Hogan, J. \& O'Rourke, B. K. (2017) Elite formation in the higher education systems of Ireland and the UK: Measuring, comparing and decomposing longitudinal patterns of cabinet members. British Journal of Education Research. Available on early view at: http://onlinelibrary.wiley.com/doi/10.1002/beri.3284/full

schools, along with Oxbridge, maintained the 'incestuous links of privilege and power' with the British establishment (Scott, 1990). Hartman (2009, p. 68) points out that:

Only three of 12 prime ministers since 1945 have not studied at Oxford or Cambridge, among them Churchill, who chose a career as an officer instead. John Major, another of those without any such exclusive education, headed a Cabinet of 23, 18 of whom were Oxbridge graduates. This was also the case for 12 of his 18 permanent secretaries.

In 2010, David Cameron became the $10^{\text {th }}$ of 13 post-war British prime ministers to have studied at Oxbridge. Hartman (2009) remarks that post-war Conservative cabinets have a higher percentage of Oxbridge graduates than Labour. In Cameron's initial Conservative/Liberal coalition cabinet of 24 ministers in 2010, 14 were Oxbridge graduates, as were 17 of Thatcher's 22 ministers in 1979; compared to just 3 of 22 ministers in Blair's 1997 Labour administration. This is interesting, given how the British Labour and Conservative parties have traditionally represented distinct cleavages in that society. Additionally, we found that by the mid 1990s, those with a higher education were disproportionally represented in Irish cabinets. However, all of this information, along with the implications of Hartman's (2009) remarks, relies upon simple observations, rich description and context, a qualitatively heavy approach that we wish to augment here with a quantitative approach.

\section{Methodology}

'Comparative historical analysis has a long history in the social sciences' (Mahoney and Rueschemeyer 2003, p. 3). As Lieberman (2001, 5) recommends, in addition to cross country cases, comparative historical analyses covering longer time spans are beneficial as 
This is the final submitted version of the paper the published version of which is Feeney, S., Hogan, J. \& O'Rourke, B. K. (2017) Elite formation in the higher education systems of Ireland and the UK: Measuring, comparing and decomposing longitudinal patterns of cabinet members. British Journal of Education Research. Available on early view at: http://onlinelibrary.wiley.com/doi/10.1002/beri.3284/full

this provides assessments of the types and magnitudes of change. Such an approach is defined by 'the use of systematic and contextualized comparison' (Mahoney and Rueschemeyer 2003 , p. 3). To address these recommendations, we draw our data from the two countries, over a 75 year period (1937-2012) that is divided into five separate 15 year increments.

1937 was chosen as our start point as that year saw the introduction of the Bunreacht na hÉireann (Constitution of Ireland), which established Ireland's cabinet government under a parliamentary system modelled on Westminster, (Farrell, 1971), making the two polities more comparable. By choosing 1937 we also incorporated cabinets whose formation was influenced by the pre-1945 social structure, giving a richer context for our work. Increments of 15 years were chosen for a number of reasons. These increments encompass at least three general elections each and possible changes of government - to ensure that no one political party dominates a time period. Given that our focus is on the role of higher education institutions in elite formation, incorporating three elections was more likely to show an underlying trend connected with the structure of the system rather the political choices made as a result of more contingent electoral influences. Of course, influences from electoral outcome and structural changes are not entirely separable, but if our focus had been, for example, on highlighting particular prime ministerial choices a shorter period would have been chosen. Although the mean number of years of cabinet membership from our data is a little over seven for Ireland and a little under five for the UK, it is known that tenure can be quite variable and that educational background seems to add to durability of ministerial tenure (Berlinski, Dewan \& Dowding 2007). Furthermore, since membership of a cabinet is often the pinnacle of a political career and a demanding job, 15 years was selected as a length of time over which there was likely to be significant turnover of cabinet membership. Though 
This is the final submitted version of the paper the published version of which is Feeney, S., Hogan, J. \& O'Rourke, B. K. (2017) Elite formation in the higher education systems of Ireland and the UK: Measuring, comparing and decomposing longitudinal patterns of cabinet members. British Journal of Education Research. Available on early view at: http://onlinelibrary.wiley.com/doi/10.1002/beri.3284/full

longer periods are likely to reveal longer term trends other things being equal, the longer the period the less change can be noticed.

Relying upon the thick description and the largely qualitative approaches traditionally associated with elite research, not only to understand the social forces, but merely to get a sense of the quantities, is problematic due to the multidimensionality of elite formation. Consequently, the O'Rourke, Hogan and Donnelly (2015) elite formation indices are used here, as they make this multidimensionality manageable by decomposing how elite a particular system of institutions is in the formation of a specific societal group (for example. how elite the UK higher education system is in relation to the composition of the UK cabinet), by capturing measures of the influence and exclusivity of that system. What's more, these wholly quantitative indices can be employed in comparing elite formation systems both synchronically (to compare elites in different countries, or different elites in the same country), and diachronically (to examine whether a formation system is becoming more/less elite over time).

Below, we further describe the index we use to measure the overall eliteness of the formation systems. However, as the influence and exclusivity of a system of institutions is more complex than intuition suggests, we will examine indices of influence and exclusiveness separately, before they are combined into an overarching eliteness index. Their use will provide directly comparable answers to the questions of to what extent did the higher education systems play a role in the formation of the governing political elites in each country and to what extent are those higher education systems limited in whom they admit.

\section{Measuring the influence of elite formation systems}


This is the final submitted version of the paper the published version of which is Feeney, S., Hogan, J. \& O'Rourke, B. K. (2017) Elite formation in the higher education systems of Ireland and the UK: Measuring, comparing and decomposing longitudinal patterns of cabinet members. British Journal of Education Research. Available on early view at: http://onlinelibrary.wiley.com/doi/10.1002/beri.3284/full

In using O'Rourke, Hogan and Donnelly’s (2015) Institutional Influence Index (I-Index), the influence of a set of elite formation institutions comprises two dimensions: the proportion of the selected elite associated with those institutions, along with the limited number of the institutions. Employing traditional qualitative methods, both of these dimensions of institutional influence (share and fewness) have made it challenging to compare the role of institutions in the production of elites across countries, as one dimension may be higher and the other lower, making it increasingly complex to keep in mind both dimensions as one compares an increasing number of countries. The I-Index of a system of institutions (in this case higher education institutions), is the sum, across the number of institutions $(n)$, of squared shares $(s)$ of affiliates (graduates ${ }^{1}$ ) of each institution $(i)$ in the elite (cabinet), so that

$$
I=\sum_{i=1}^{i=n}\left(\frac{m_{i}}{M}\right)^{2}
$$

where $m_{i}$ is the number of affiliates of institute $i$ that are members of the elite in question and $M$ is the total number of members of that elite (O'Rourke, Hogan and Donnelly, 2015). This is an adaption of the Herfindahl-Hirschman Index (H-Index) employed in industrial economics - to measure supplier concentration in a particular market for institutional socialisation of services to particular elites (Davies et al. 1991, 82).

The influence of the higher education systems on the formation of cabinet ministers depends upon the proportion of ministers educated in specific higher education institutions along with the limited number of those higher education institutions in the countries of interest. Thus, the I-Index goes up if, a greater proportion of those in ministerial office are

\footnotetext{
${ }^{1} \mathrm{We}$ are only looking at where ministers, in both countries, acquired their primary degrees
} 
This is the final submitted version of the paper the published version of which is Feeney, S., Hogan, J. \& O'Rourke, B. K. (2017) Elite formation in the higher education systems of Ireland and the UK: Measuring, comparing and decomposing longitudinal patterns of cabinet members. British Journal of Education Research. Available on early view at: http://onlinelibrary.wiley.com/doi/10.1002/beri.3284/full

graduates of any one higher education institution. The value of the I-Index will also increase if there are fewer higher education institutions involved in producing members of the political elite.

\section{Measuring the exclusivity of elite formation systems}

The other side of elite formation is the exclusivity of the institutions involved. As with measuring institutional influence, O'Rourke, Hogan and Donnelly, (2015) argue that the exclusivity of a set of elite formation institutions comprises two dimensions. Firstly, the more alternatives there are to any one institution, the more exclusiveness there can be. Secondly, the more unequal the shares of each institution the more exclusiveness there is. They developed a more practicable exclusivity index for studying elite formation systems, the XE-Index, which focuses on the elite formation element thereby efficiently reducing the data requirements of their measure. Where, $\mathrm{P}$ is the total relevant general population (all 18-25 year olds in a country as per its census), $p_{k}$ is the population in the $k^{\text {th }}$ elite higher education institution, and $t$ is the number of elite institutions (number of higher education institutes), then

$$
X E=\left[\frac{\sum_{k=1}^{k=t} 1-\left(\frac{p_{k}}{P}\right)^{0.5}}{t}\right]
$$

The XE-Index measures the exclusiveness of elite higher education institutions only. It is not affected by the how non-elite institutions (higher education institutions without graduates in the elite group - cabinet) vary in size. The XE-index also measures changes in both the proportion of the relevant population that goes to elite higher education institutions and how that proportion is shared out among those institutions. 
This is the final submitted version of the paper the published version of which is Feeney, S., Hogan, J. \& O'Rourke, B. K. (2017) Elite formation in the higher education systems of Ireland and the UK: Measuring, comparing and decomposing longitudinal patterns of cabinet members. British Journal of Education Research. Available on early view at: http://onlinelibrary.wiley.com/doi/10.1002/beri.3284/full

\section{Combining influence and exclusivity measures into a measure of the eliteness of an elite formation system}

The elite index of a system of institutions requires a measure that links influence and exclusivity at the level of each institution, before aggregation to the level of the system. An institution may be very influential, in the sense of having many affiliates (in this case graduates) in influential positions in a country, but be so inclusive that it cannot be claimed to contribute to the eliteness of the system. Similarly, institutions may be exclusive, without being influential, if they have no affiliates in the elite being measured. Thus, eliteness is the linked combination of influence and exclusivity. O'Rourke, Hogan and Donnelly (2015) combine their influence and exclusivity measures into a linked Institutional Eliteness Index (E-Index)

$$
\mathrm{E}=\sum_{i=1}^{i=n}\left(\frac{m_{i}}{M}\right)^{2}\left(1-\left(\frac{p_{i}}{P}\right)^{0.5}\right)
$$

For this study, $m_{i}$ is the number of affiliates (graduates) of institution (university) $i$ that are members of the elite in question (the cabinet) and $M$ is the total number of members of that elite. $P$, as above, is the total number in the relevant general population (all 18-25 year olds in the countries being examined) and $p_{i}$ is the number of the relevant population in higher education institution $i$. In calculating $\mathrm{E}$, there is no need for individual information on non-elite higher education institutions, since the $I_{i}$ of non-elite higher education institutions will be zero, so such information will count for nought in the calculated E-Index.

If any institution's affiliates have a larger share of membership of the elite (the cabinet), then the E-Index will rise. If an elite-producing institution takes a smaller share of the general population, this increased exclusivity of the institution will be reflected in a rise in 
This is the final submitted version of the paper the published version of which is Feeney, S., Hogan, J. \& O'Rourke, B. K. (2017) Elite formation in the higher education systems of Ireland and the UK: Measuring, comparing and decomposing longitudinal patterns of cabinet members. British Journal of Education Research. Available on early view at: http://onlinelibrary.wiley.com/doi/10.1002/beri.3284/full

the E-Index. An advantage of these indices is that the results that can be generated move between zero and one, with zero representing no influence, exclusivity or eliteness, and one representing the opposite. Consequently, the indices produce results that are easily comparable across institutions, jurisdictions and time.

\section{Data and Procedures}

We focus upon the higher education institutions attended by cabinet ministers in Ireland and the UK in the period 1937-2012 to gain an insight into the eliteness of these higher education systems. We acquired this data from examining each of the ministers' CVs. We specifically examine the data in five 15 year increments in order to provide a sense of how the findings change over time (1937-1952; 1952-1967; 1967-1982; 1982-1997; 1997-2012) along with one overarching 75 year increment. This constitutes one of the basic techniques for periodization used by historians (Gould 1997; Hollander et al, 2005). Of course, the employment of periods, in general, constitutes a tendency towards oversimplification, but it is useful in promoting understanding (Clark, 1967).

The findings will enable us see how an elite formation system's eliteness, influence and exclusiveness varies over time both within (diachronically) and between (synchronically) the two countries. Under the Irish Constitution (Articles 28.1 and 28.2), the cabinet is vested with executive authority, constituting the government, and shall consist of no less than 7 and no more than 15 members, though it usually consists of 15 members. In the UK, the average cabinet consists of the Prime Minister and 19 senior ministers (Buckley, 2006).

Between 1937, when Ireland adopted a form of cabinet government similar to that in the UK, and 2012, there were 157 ministers in Irish governments - 106 of whom graduated from 12 universities; and 340 ministers in UK governments - 290 of whom graduated from 
This is the final submitted version of the paper the published version of which is Feeney, S., Hogan, J. \& O'Rourke, B. K. (2017) Elite formation in the higher education systems of Ireland and the UK: Measuring, comparing and decomposing longitudinal patterns of cabinet members. British Journal of Education Research. Available on early view at: http://onlinelibrary.wiley.com/doi/10.1002/beri.3284/full

44 universities. Although these numbers might appear low - senior politicians are often reappointed to ministerial office in various governments. While Ireland had 29 governments between 1937 and 2012, to 19 in the UK, cabinet reshuffles on a larger scale were more common in the UK as were ministerial transitions.

Using the E-Index, we compare the eliteness of the Irish and UK higher education systems in the formation of cabinets in Ireland and the UK. In this context, crucial to measuring the institutional influence of the higher education institutions, is how their affiliates' (graduates) membership of the elite group, in this case the cabinet, is counted. A straightforward way is to count every cabinet minister who is an affiliate of a higher education institution, regardless of how long that person was in the elite group, or how many portfolios they held. For example, Kenneth Clarke and Angus Maude, both members of UK cabinets, would enter our measure of institutional influence as one for Cambridge and one for Oxford, respectively. However, it is worth considering the implications of this, as we selected Clarke and Maude due to their differing cabinet experiences. Clarke served for over 20 years in British cabinets, held numerous portfolios, being Chancellor of the Exchequer for almost four years; while Maude was in cabinet for only a year and a half and only held one portfolio. Nevertheless, these very different cabinet experiences will contribute equally to the influence and eliteness indices. This method is adopted as once a person has become a cabinet minister, it may be that this is the key influence on their continuing in cabinet, rather than the higher education institution that they attended.

Crucial to measuring exclusivity is the total number in the relevant general population and the number of the relevant general population in each elite producing institution. For our measures of the relevant general population $(\mathrm{P})$, we took the average total population of 1825 year olds in each jurisdiction in the five 15 year periods under examination from census 
This is the final submitted version of the paper the published version of which is Feeney, S., Hogan, J. \& O'Rourke, B. K. (2017) Elite formation in the higher education systems of Ireland and the UK: Measuring, comparing and decomposing longitudinal patterns of cabinet members. British Journal of Education Research. Available on early view at: http://onlinelibrary.wiley.com/doi/10.1002/beri.3284/full

data. For $p_{i}$ we took the average number of students attending each elite producing higher education institutions in each of the periods. This data, displayed in the linked datasets ${ }^{2}$ and sampled in the Appendices, was acquired from public records in Ireland; and from disbursed public databases in the UK, through requests to British universities, or ancestor institutions of historic British universities and occasionally through Freedom of Information (FOI) requests in the UK. We chose this approach as it shows the indices working with historically accurate, if not readily available, data.

In the linked datasets, and also sampled in the appendices (Tables A6 and B6), we produce a table looking at the influence, exclusiveness and eliteness of the higher education institutions producing cabinet ministers over the whole 75 years. This is done using 2012 data for the total number in the relevant general population and the number of the relevant general population in each elite producing institution.

By providing measures for the eliteness, influence and exclusivity of higher education systems producing cabinet ministers in five periods - we can see how elite formation systems change over time within and between countries. As elite formation in Ireland and the UK is well understood, our findings can be examined in the context of previous qualitative work (Cohan 1972; 1973; Hartmann 2009; Kennedy and Power 2010; O’Rourke, Hogan, and Donnelly 2015; Van Zanten 2010; Van Zanten and Ball 2015).

\section{Results and Discussion}

In Appendix A, we show samples of the detailed calculations contained in the linked datasets for the E-Index, I-Index and XE-Index for the higher education institutions that provided Irish government ministers in each of the five periods between 1937 and 2012, along with a

\footnotetext{
${ }^{2}$ The links to these datasets are provided at the end of the paper.
} 
This is the final submitted version of the paper the published version of which is Feeney, S., Hogan, J. \& O'Rourke, B. K. (2017) Elite formation in the higher education systems of Ireland and the UK: Measuring, comparing and decomposing longitudinal patterns of cabinet members. British Journal of Education Research. Available on early view at: http://onlinelibrary.wiley.com/doi/10.1002/beri.3284/full

unified table looking at the whole 75 years. Appendix B shows similar calculations for the UK, with a link to the comprehensive datasets.

\section{E-Index Scores for Ireland and the UK}

In Table 1, we set out the values of the E-Index for the higher education systems in Ireland and the UK that supplied ministers to Irish and British cabinets in each of the five 15 year periods between 1937 and 2012. We also provide an E-index value for the whole 75 years.

Table 1: Elite indices for the Irish and UK HE systems supplying cabinet ministers.

\begin{tabular}{|l|c|c|c|c|c|c|}
\hline & \multicolumn{6}{|c|}{ E-Index* } \\
\hline & $\mathbf{1 9 3 7 - 1 9 5 2}$ & $\mathbf{1 9 5 2 - 1 9 6 7}$ & $\mathbf{1 9 6 7 - 1 9 8 2}$ & $\mathbf{1 9 8 2 - 1 9 9 7}$ & $\mathbf{1 9 9 7 - 2 0 1 2}$ & $\mathbf{1 9 3 7 - 2 0 1 2}$ \\
\hline Ireland & 0.0630 & 0.076 & 0.1837 & 0.1503 & 0.1741 & $\mathbf{0 . 1 0 5 9}$ \\
\hline $\begin{array}{l}\text { United } \\
\text { Kingdom }\end{array}$ & 0.1756 & 0.2588 & 0.1975 & 0.2710 & 0.1212 & $\mathbf{0 . 1 5 1 5}$ \\
& & & & & & \\
\hline
\end{tabular}

*These rounded values are taken from calculations presented in the appendices and detailed in the datasets.

From Table 1, we can see that the E-Index for the higher education system in Ireland was lower than that for the UK in four of the five periods. The gap between the E-indices for both countries was particularly wide during 1952-1967. However, after 1997, when New Labour came to power in Britain, the eliteness of the Irish higher education system exceeded the British. This was partly because UK cabinets from 1997 consisted of Labour minsters educated in a broader range of higher education institutions than was traditionally the case, particularly in the preceding Conservative administrations. While the actual number of 
This is the final submitted version of the paper the published version of which is Feeney, S., Hogan, J. \& O'Rourke, B. K. (2017) Elite formation in the higher education systems of Ireland and the UK: Measuring, comparing and decomposing longitudinal patterns of cabinet members. British Journal of Education Research. Available on early view at: http://onlinelibrary.wiley.com/doi/10.1002/beri.3284/full

British ministers from Oxbridge was almost the same in 1982-1997 and 1997-2012 (see Appendix B, Tables B4 and B5), in the former period Oxbridge graduates made up 75 percent of all ministers, whereas in the latter period this fell to 46 percent.

Figure 1: E-index trends for Irish and UK higher education systems supplying cabinet ministers.

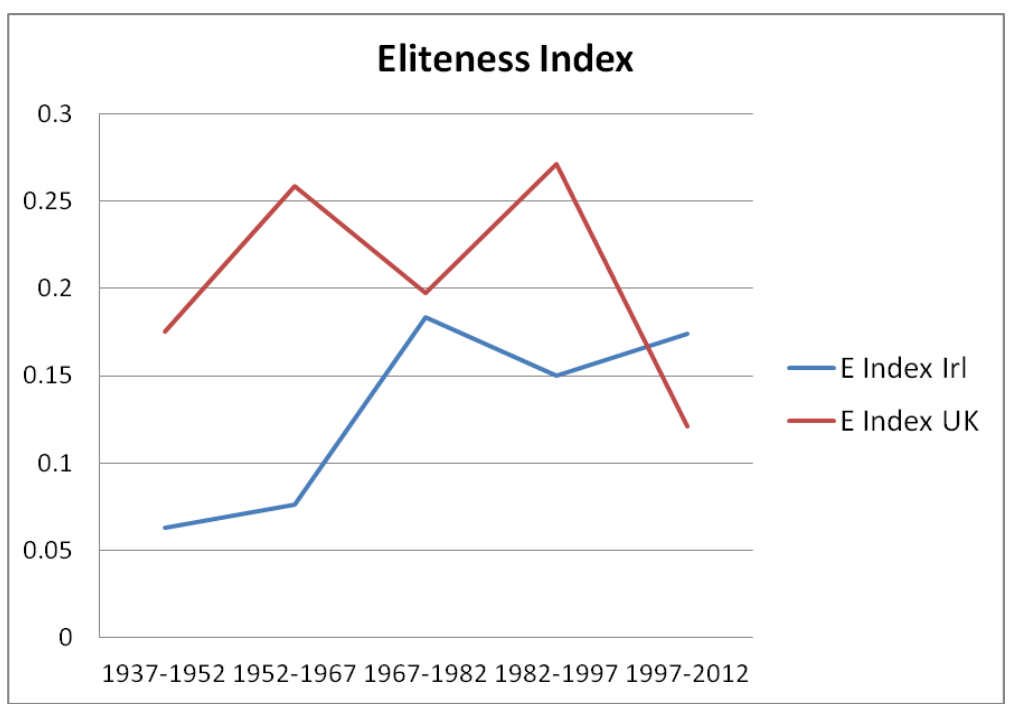

From Figure 1, we can see that historically, while the UK higher education institutions supplying cabinet ministers were more elite than their Irish counterparts, this trend reversed after 1997. In the overall context from 1937 to 2012, the UK higher education system was one-and-a-half times more elite than the Irish system; 0.1515 to 0.1059 (see Table 1). These findings, as they relate to 1937-1997, are consistent with the picture painted by others (see Cohan 1972; 1973; Hartmann 2009; Keating and Cairney 2006; Parry, 2005) relying more on thick description and impressionistic evidence than the quantitative approach adopted here. Our findings post-1997 are somewhat of a surprise to those of us familiar with the less elitist feel of Irish society and government and thus illustrate the usefulness of the quantitative approach chosen. . 
This is the final submitted version of the paper the published version of which is Feeney, S., Hogan, J. \& O'Rourke, B. K. (2017) Elite formation in the higher education systems of Ireland and the UK: Measuring, comparing and decomposing longitudinal patterns of cabinet members. British Journal of Education Research. Available on early view at: http://onlinelibrary.wiley.com/doi/10.1002/beri.3284/full

\section{I-Index Scores for Ireland and the UK}

From Table 2, we can see that the I-Index scores for Ireland were initially much lower than in the UK (1937-1952; 1952-1967). However, over the following three periods the I-index scores for the Irish higher education system supplying cabinet ministers exceeded the UK system twice (1967-1982; 1997-2012). In an overall context, looking at the period 19372012 as a whole, the UK higher education system's I-index of 0.1618 was slightly more influential than its Irish counterparts' score of 0.1366 . This reflects the impression one gets from a more intimate reading of the situation, the dominant position of Oxbridge in supplying UK cabinet ministers between 1937 and 2012 does not have an Irish equivalent - although UCD comes close (See Appendices A6 and B6). In fact, the I-index scores for Oxbridge account for most of the I-index scores for the British higher education system.

Table 2: Influence Indices for the Irish and UK HE systems supplying cabinet ministers.

\begin{tabular}{|l|c|c|c|c|c|c|}
\hline & \multicolumn{6}{|c|}{ I-Index* } \\
\hline & $\mathbf{1 9 3 7 - 1 9 5 2}$ & $\mathbf{1 9 5 2 - 1 9 6 7}$ & $\mathbf{1 9 6 7 - 1 9 8 2}$ & $\mathbf{1 9 8 2 - 1 9 9 7}$ & $\mathbf{1 9 9 7 - 2 0 1 2}$ & $\mathbf{1 9 3 7 - 2 0 1 2}$ \\
\hline Ireland & 0.0688 & 0.0868 & 0.2150 & 0.1795 & 0.2175 & $\mathbf{0 . 1 3 6 6}$ \\
\hline $\begin{array}{l}\text { United } \\
\text { Kingdom }\end{array}$ & 0.1821 & 0.2702 & 0.2069 & 0.2866 & 0.1295 & $\mathbf{0 . 1 6 1 8}$ \\
\hline
\end{tabular}

*These rounded values are taken from calculations presented in the appendices and detailed in the datasets. 
This is the final submitted version of the paper the published version of which is Feeney, S., Hogan, J. \& O'Rourke, B. K. (2017) Elite formation in the higher education systems of Ireland and the UK: Measuring, comparing and decomposing longitudinal patterns of cabinet members. British Journal of Education Research. Available on early view at: http://onlinelibrary.wiley.com/doi/10.1002/beri.3284/full

In Figure 2, we can see the trends in the I-index for the higher education systems in both countries. Where the UK's I-index score started off much higher, in the last generation this trend reversed.

Figure 2: I-index trends for Irish and UK HE systems supplying cabinet ministers.

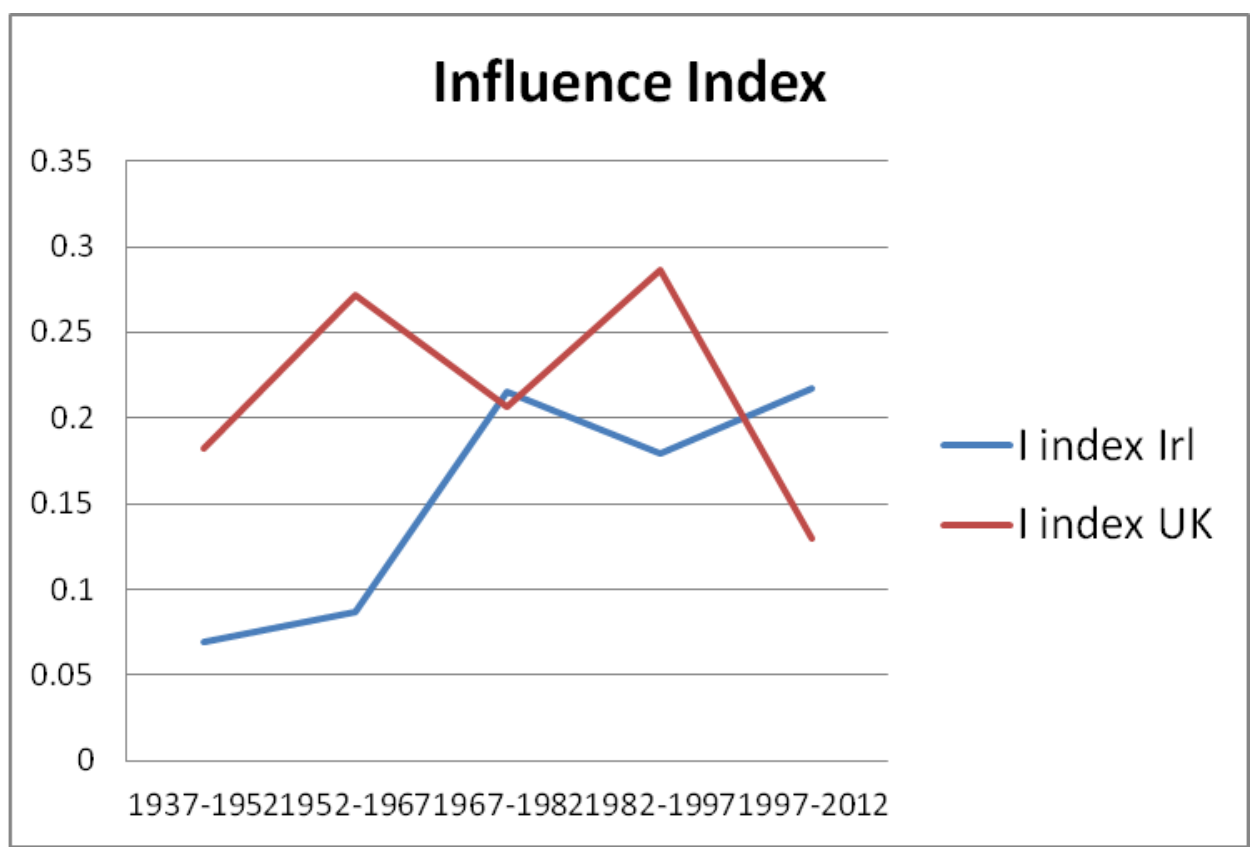

Should any of the I-Index values set out in Table 2 be considered high, or too high? The answer to this question lies in comparison. The construction of the I-index, drawing as it does on the industrial economics measure (H-Index), means we have another source of comparative values. Thus, I-Index values, effectively a measurement of supplier (higher education institution) concentration in the production of ministers in both countries, can be compared to values of the H-Index for different markets. In industrial economics, markets with a H-Index of less than 0.2 would be considered competitive. Thus, from an industrial economics perspective, one that views universities as sellers and cabinets as buyers, there is evidence that monopoly power was held by higher education institutions in supplying 
This is the final submitted version of the paper the published version of which is Feeney, S., Hogan, J. \& O'Rourke, B. K. (2017) Elite formation in the higher education systems of Ireland and the UK: Measuring, comparing and decomposing longitudinal patterns of cabinet members. British Journal of Education Research. Available on early view at: http://onlinelibrary.wiley.com/doi/10.1002/beri.3284/full

ministers to UK cabinets during three periods (1952-1967; 1967-1982; 1982-1997); and by higher education institutions in supplying Irish ministers in two periods (1967-1982; 19972012).

Of course, concerns about higher education institutions supplying cabinet ministers are broader than the traditional industrial economics concern with monopoly power. First, there is the social concern about the lack of diversity in elite formation (Genieys and Smyrl 2008) - a governing elite that lacks diversity may be more subject to groupthink (Froud et al. 2011). Janis (1982) pointed to damaging examples of groupthink through examining policy decisions from the Attack on Pearl Harbor to the escalation of the Vietnam War. Secondly, there is the issue of how representative governing elites are of the general population? Thirdly, there is the social concern that the exclusivity of those higher education institutions is unfairly restricting access to elite positions. The first two concerns mean that we might have issues at lower levels of the I-index than industrial economics would lead us to expect. The third concern, unfair restriction of opportunity, is more directly addressed by the exclusivity or XE-Index.

\section{XE-Index Scores for Ireland and the UK}

From Table 3, we can see that the XE-Index for the Irish higher education system supplying cabinet ministers was below that in the UK for each of the periods and in the overall 19372012 context. From this we can conclude that the higher education system in the UK was slightly more exclusive than the Irish system. Thus, the chances of a British citizen attending one of the UK's elite higher education institutions is a slightly more uncommon experience than for their Irish counterparts. 
This is the final submitted version of the paper the published version of which is Feeney, S., Hogan, J. \& O'Rourke, B. K. (2017) Elite formation in the higher education systems of Ireland and the UK: Measuring, comparing and decomposing longitudinal patterns of cabinet members. British Journal of Education Research. Available on early view at: http://onlinelibrary.wiley.com/doi/10.1002/beri.3284/full

Table 3: Exclusiveness indices for the Irish and UK HE systems supplying cabinet ministers.

\begin{tabular}{|l|c|c|c|c|c|c|}
\hline & \multicolumn{6}{|c|}{ XE-Index* } \\
\hline & $\mathbf{1 9 3 7 - 1 9 5 2}$ & $\mathbf{1 9 5 2 - 1 9 6 7}$ & $\mathbf{1 9 6 7 - 1 9 8 2}$ & $\mathbf{1 9 8 2 - 1 9 9 7}$ & $\mathbf{1 9 9 7 - 2 0 1 2}$ & $\mathbf{1 9 3 7 - 2 0 1 2}$ \\
\hline Ireland & 0.9290 & 0.9164 & 0.9159 & 0.9033 & 0.8663 & $\mathbf{0 . 8 7 0 2}$ \\
\hline $\begin{array}{l}\text { United } \\
\text { Kingdom }\end{array}$ & 0.9762 & 0.9720 & 0.9684 & 0.9606 & 0.9454 & $\mathbf{0 . 9 4 6 9}$ \\
& & & & & & \\
\hline
\end{tabular}

*These rounded values are taken from calculations presented in the appendices and detailed in the datasets.

In Figure 3, we see that the trends in the XE-index, in both countries, are pointing downwards. Clearly, the rate of decrease in the exclusivity of the higher education institutions was faster in Ireland than in the UK over the past two generations. This was a time when the number of higher education places in each Irish higher education institutions grew rapidly while the relevant general population of the country expanded more slowly. ${ }^{3}$ It was also a time when the number of places in UK higher education institutions expanded at a slower rate in comparison to the relevant general population and, of course, in comparison to Ireland - as is borne out by the results in Table 3 and the trend lines in Figure 3.

Figure 3: XE-index trends for Irish and UK HE systems supplying cabinet ministers.

\footnotetext{
3 The total number of students studying in all Irish universities increased from 44,541 in 1982 (http://www.education.ie/en/Publications/Statistics/Statistical-Report-1981-1982.pdf) to 163,000 as of 2012, with a similar increase in student population being seen in the elite universities that supply cabinet ministers, while the relevant general population - as per Appendix A - increased at a much slower rate.
} 
This is the final submitted version of the paper the published version of which is Feeney, S., Hogan, J. \& O'Rourke, B. K. (2017) Elite formation in the higher education systems of Ireland and the UK: Measuring, comparing and decomposing longitudinal patterns of cabinet members. British Journal of Education Research. Available on early view at: http://onlinelibrary.wiley.com/doi/10.1002/beri.3284/full

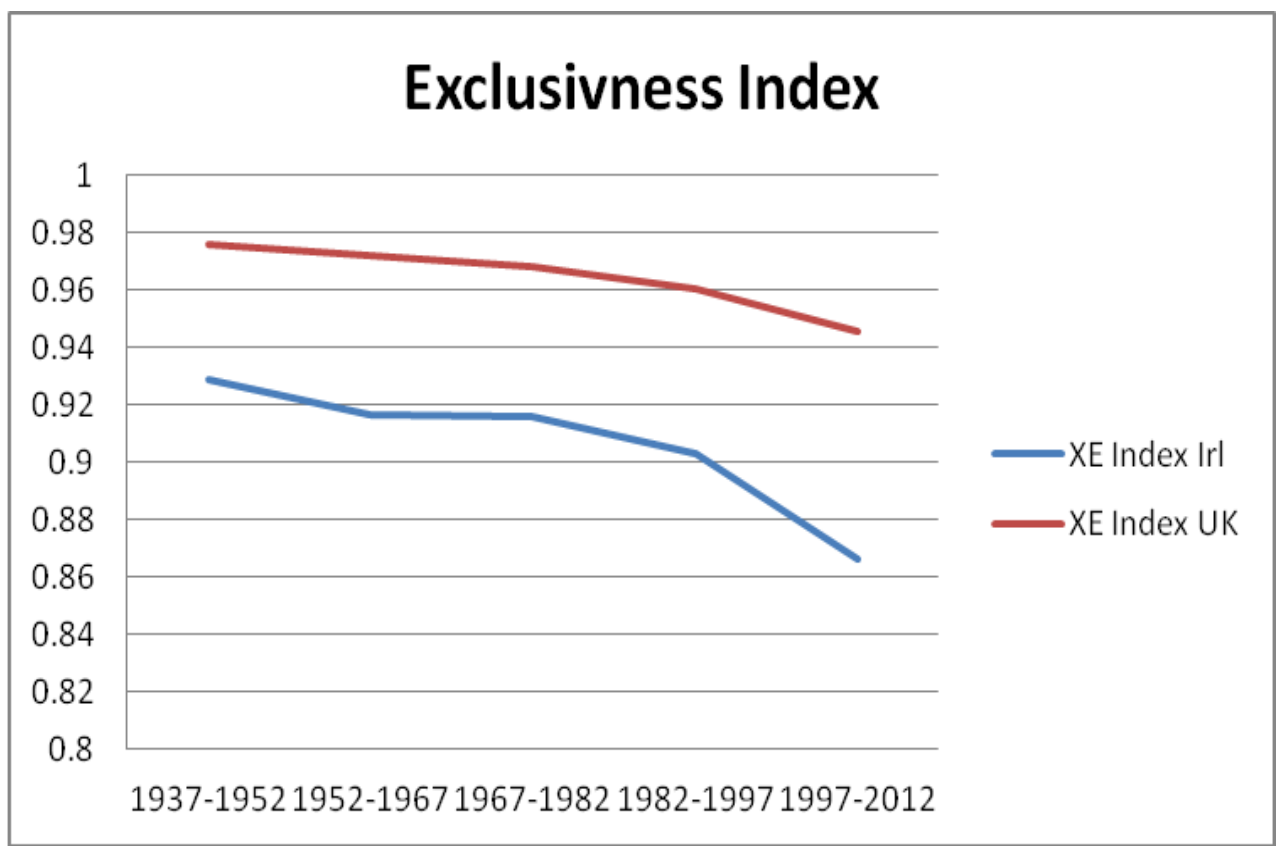

\section{Conclusion}

This study sought to measure the influence, exclusivity and eliteness, of the higher education systems in Ireland and the UK that supplied cabinet ministers in five 15 year periods between 1937 and 2012, as well as for the whole 75 years. As this approach allows us to measure three separate indices, it means that the constituent elements that compose elitenesss can be identified, quantified and compared. Through synchronic and diachronic comparisons, these indices have facilitated better understanding of the complexity of the relationships between different higher education systems, and their constituent higher education institutions, in governing elite formation, in different countries, at different times.

We found that, between 1937 and 2012, a low number of universities in Ireland and the UK, provided ministers, with even fewer providing more than one minister. The eliteness of the higher education institutions supplying cabinet ministers was greater in the UK than Ireland, with the E-index for the UK universities one and a half times that of their Irish counterparts. Up to now, while we might have had the impression that the Irish higher 
This is the final submitted version of the paper the published version of which is Feeney, S., Hogan, J. \& O'Rourke, B. K. (2017) Elite formation in the higher education systems of Ireland and the UK: Measuring, comparing and decomposing longitudinal patterns of cabinet members. British Journal of Education Research. Available on early view at: http://onlinelibrary.wiley.com/doi/10.1002/beri.3284/full

education institutions was less elite than the UK system, it had never been quantitatively scrutinized in such a directly comparable fashion and over such a long period. This scrutiny reveals the rather surprising finding that in the period 1997-2012, the eliteness of the Irish higher education system surpassed that of the UK due to increases in the eliteness of the Irish cabinet's higher education after 1997 and a decrease in the eliteness of the UK cabinet.

Overall, the concentration of influence was higher in the UK higher education system $i$ than in the Irish system, as measured by the I-index between 1937 and 2012 . However, the gap in the I-index between the two countries was much greater in 1937-1952 and 1952-1967, and narrowed thereafter. Somewhat surprisingly, the I-index for Ireland was almost twice that of the UK during 1997-2012. Thus, the influence, rather than exclusiveness, component of eliteness, made the Irish higher education system more elite in the 1997-2012 period (see Tables 1 and 2). The influence component captures the similarity of elite formation experience and therefore that element of elite formation most likely to give rise to groupthink (Froud et al. 2011).

The XE-index measure of exclusiveness for the UK higher education system supplying cabinet ministers was slightly higher than for Ireland in each of the 15-year periods, as well as overall. However, in both countries the XE-index was trending downwards. The gap between the Irish and UK XE-index widened gradually, partly reflecting the rapid expansion of the Irish higher education sector from the 1980s onwards and the increasing access to Irish higher education. By the 1997-2012 period the populations attending elite universities in Ireland also constituted a higher percentage of the total relevant population compared to the UK (see linked datasets).

The fall in the eliteness of the UK's higher education institutions supplying cabinet ministers in the period 1997-2012 was largely due to more ministers in the Blair and Brown 
This is the final submitted version of the paper the published version of which is Feeney, S., Hogan, J. \& O'Rourke, B. K. (2017) Elite formation in the higher education systems of Ireland and the UK: Measuring, comparing and decomposing longitudinal patterns of cabinet members. British Journal of Education Research. Available on early view at: http://onlinelibrary.wiley.com/doi/10.1002/beri.3284/full

Labour administrations coming from a wider range of universities than was traditionally the case. It might be expected that the eliteness of the higher education systems attended by senior politicians will again be greater in the UK. This is because of the 2010 return to power of the Conservatives, who traditionally draw a disproportionate number of their ministers from Oxbridge, and the fact that UK universities now charge fees, which will discourage some people from attending university. In 2016, UK fees reached $£ 9,250$ (Potts, 2016). Furthermore, the increase in eliteness in Ireland in 1997-2012 was driven by the rise in the influence, as opposed to increased exclusiveness, of particular Irish higher education institutions in the 1997-2012 period. This increased influence may be due, at least in part to several contingencies that might be expected to be short-lived. In particular, the dominance of just two degree-awarding higher education institutes in Dublin until 1975 and the taboo on Roman Catholics attending one of them until 1970.

Regardless of the possibly contingent nature of the degree of influence and exclusiveness, theory would suggest that these aspects of elite formation of the higher education system are important. If exclusiveness is high in a higher education elite formation system the argument that this higher education system is making elite-formation more meritocratic is weak, unless it can be argued that exclusiveness is achieved by meritocratic selection. Although the claim that exclusivity is meritocratic in higher education might be easier to defend than exclusivity at post-primary level, there is reason to be sceptical of claims that exclusivity in higher education institutions is achieved meritocratically (Dunne, King and Ahrens, 2014; Kennedy and Power, 2010). If influence is high in elite formation, then there are good reasons to think that important decisions may be made with an overly restricted viewpoint - as there will be a lack of diversity amongst those making the decisions (Axelrod 2015; Power et al. 2013). 
This is the final submitted version of the paper the published version of which is Feeney, S., Hogan, J. \& O'Rourke, B. K. (2017) Elite formation in the higher education systems of Ireland and the UK: Measuring, comparing and decomposing longitudinal patterns of cabinet members. British Journal of Education Research. Available on early view at: http://onlinelibrary.wiley.com/doi/10.1002/beri.3284/full

The indices used here, providing a breakdown into exclusiveness and influence of the components of elite formation systems, constitute a significant advance in researching the role of higher education systems in elite formation. While not supplanting the relevance of contextual analysis; the indices are useful tools for those seeking to directly compare elites across jurisdictions and time.

\section{References}

Alley, S., and Smith, M. (2004) “Timeline: tuition fees.” The Guardian, January 27. Available online at: http://www.theguardian.com/education/2004/jan/27/tuitionfees.students (accessed 12 May 2016)

Anderson, R. D. (1995) Universities and Elites in Britain Since 1800. $2^{\text {nd }}$ ed, (Cambridge, Cambridge University Press).

Axelrod, R. (2015). Structure of Decision: The Cognitive Maps of Political Elites. (Princeton NJ, Princeton University Press)

Bachrach, P. (1971) Introduction, in P. Bachrach (ed), Political Elites in a Democracy, New Brunswick, NJ: Transaction Publishers.

Bond, M. (2012) The Bases of Elite Social Behaviour: Patterns of Club Affiliation among Members of the House of Lords, Sociology, 46(4), 613-632.

Berlinski, S., Dewan, T., \& Dowding, K. (2007). The Length of Ministerial Tenure in the United Kingdom, 1945-97. British Journal of Political Science, 37(2), 245-262.

Borjesson, M. Broady, D., Dalberg, T., and Lindegran, I. (2016). Elite Education in Sweden, in C. Maxwell and P.Aggleton (eds). Elite Education: International Perspectives. Abingdon: Routledge.

Botella, J., Teruel, J. R., Barberá, O. and Barrio A. (2010). A new political elite in Western Europe? The political careers of regional prime ministers in newly decentralised countries. French Politics 8(1): 42-61.

Bourdieu, P. (1989) Social space and symbolic power, Sociological Theory, 71(1), 14-25.

Bourdieu, P. (1996) The State Nobility: Elite Schools in the Field of Power (L.C. Clough, Trans.), (Cambridge, Polity Press). 
This is the final submitted version of the paper the published version of which is Feeney, S., Hogan, J. \& O'Rourke, B. K. (2017) Elite formation in the higher education systems of Ireland and the UK: Measuring, comparing and decomposing longitudinal patterns of cabinet members. British Journal of Education Research. Available on early view at: http://onlinelibrary.wiley.com/doi/10.1002/beri.3284/full

Bourdieu, P., and Passeron, J-C. (1990) Reproduction in Education, Society and Culture. (London, Sage Publications).

Brezis, E. S., and Crouzet, F. (2006) The role of higher education institutions: Recruitment of elites and economic growth, in T. S. Eicher and C. García-Penalosa (Eds) Institutions, Development, and Economic Growth. (Cambridge, MA: Massachusetts Institute of Technology).

Buckley, S. (2006) Prime Minister and Cabinet. (Eidenburgh: Eidenburgh University Press).

Carnoy, M., Loyalka, P., Dobryakova, M., Dossani, R. Froumin, I., Kuhns, K,. Tilak,, J. B. G. and Wang, R. (2013) University Expansion in a Changing Global Economy: Triumph of the BRICs? Stanford, CA: Stanford University Press.

Citizens Information, (2015) "Third-level student fees and charges." Available online at: http://www.citizensinformation.ie/en/education/third_level_education/fees_and_supports_for _third_level_education/fees.html (accessed 2 April 2015).

Clark, Kitson. (1967) The critical historian. (London: Heinemann).

Cohan, A. S. (1972) The Irish Political Elite, (Dublin, Gill and Macmillan).

Cohan, A. S. (1973) Career patterns in the Irish political elite, British Journal of Political Science, 3(2), 213-228.

Cotta, M. (1984). Direct elections of the European parliament: A supranational political elite in the making. In: K. Reif (ed.) European Elections 1979/81 and 1984: Conclusions and Perspectives from Empirical Research, pp. 122-126. Berlin: Quorum,.

Courtois, A. (2012) Becoming Elite: Exclusion, Excellence, and Collective Identity in Ireland's Top Fee-Paying Schools, in J. Abbink and T. Salverda (Eds), The Anthropology of Elites: Power, Culture, and the Complexities of Distinction. (Basingstoke: Palgrave Macmillan).

Daguerre, A., (2014) New corporate elites and the erosion of the Keynesian social compact, Work, Employment \& Society, 28 (2), 323-334. doi:10.1177/0950017013496303

Davies, S., Lyons, B., Dixon, H., \& Geroski, P. (1991). Economics of industrial organisation, (London, Longman).

Dye, T. R., and Zeigler, H. (2006) The Irony of Democracy: an uncommon introduction to American Politics. Belmont: Thomson.

Desmond, M., (2004) Methodological challenges posed in studying an elite in the field, Area, 36 (3), 262-69. doi: 10.1111/j.0004-0894.2004.00223.x

Domhoff, W. (1967) Who Rules America (Engelwood Cliffs, NJ, Prentice Hall). 
This is the final submitted version of the paper the published version of which is Feeney, S., Hogan, J. \& O'Rourke, B. K. (2017) Elite formation in the higher education systems of Ireland and the UK: Measuring, comparing and decomposing longitudinal patterns of cabinet members. British Journal of Education Research. Available on early view at: http://onlinelibrary.wiley.com/doi/10.1002/beri.3284/full

Dunne, M., King, R. and Ahrens, J. (2014) Applying to higher education: comparisons of independent and state schools, Studies in Higher Education, 39 (9), 1649-1667.

Fanning, B. (2002) Racism and Social Change in the Republic of Ireland (Manchester, Manchester University Press).

Farrell, B. (1971) Chairman or Chief?: The Role of Taoiseach in Irish Government (Dublin, Gill and Macmillan).

Farrell, B. (1994) The political role of cabinet ministers in Ireland, in M. Laver and K. A. Shepsle (eds), Cabinet Ministers and Parliamentarty Government (Cambridge: Cambridge University Press).

Feeney, S. (2014) "Institutional Quality Review in Higher Education in the Republic of Ireland and Northern Ireland: A Comparison of Two Approaches." Doctoral thesis, University of Sheffield.

Froud, J., Nilsson, A., Moran, M. and Williams, K. (2012) Stories and Interests in Finance: Agendas of Governance before and after the Financial Crisis, Governance, 25 (1), 35-59. doi:10.1111/j.1468-0491.2011.01561.x

Gallagher, M. (2009) The Oireachtas: President and Parliament, in J. Coakley and M. Gallagher.(Eds), Politics in the Republic of Ireland (5 $5^{\text {th }}$ ed.) (London: Routledge and the PSAI Press).

Genieys, W., and Smyrl, M. (2008) Inside the Autonomous State: Programmatic Elites in the Reform of French Health Policy, Governance 21 (1), 75-93. doi:10.1111/j.14680491.2007.00386.x

Gerring, J. (2007) Case Study Research: Principles and Practices. (Cambridge, Cambridge University Press).

Goldstein, W. (2004) "For Country: The (Second) Great All-Blue Presidential Race." Yale Alumni Magazine, Available online at: http://archive.yalealumnimagazine.com/issues/2004_05/presidents.html (Accessed 23 October 2015)

Gould, S. J. (1997). Questioning the millennium, (New York: Harmony).

Government of Ireland. (1995) Charting Our Education Future: White Paper on Education. (Dublin, Department of Education).

Government of Ireland. (2012) Key statistics 2011/2012. Dublin: Department of Education. Available online at: http://www.education.ie/en/Publications/Statistics/Key-Statistics2012.pdf (Accessed 15 March 2016).

Greenaway, D., and M. Haynes. (2003) Funding Higher Education in the UK: The Role of Fees and Loans, The Economic Journal, 113 (485), F150-F166. doi: 10.1111/14680297.00102 
This is the final submitted version of the paper the published version of which is Feeney, S., Hogan, J. \& O'Rourke, B. K. (2017) Elite formation in the higher education systems of Ireland and the UK: Measuring, comparing and decomposing longitudinal patterns of cabinet members. British Journal of Education Research. Available on early view at: http://onlinelibrary.wiley.com/doi/10.1002/beri.3284/full

Hartmann, M. (2009) The Sociology of Elites (London, Taylor \& Francis.Kindle edition).

Heywood, A. (2015). Essentials of UK Politics, $3^{\text {rd }}$ ed. Basingstoke: Plagrave.

Higher Education Statistics Agency. (2012). Students by HE provider. Students, Qualifiers and Staff data tables. Available online at: https://www.hesa.ac.uk/content/view/1973/239/ (accessed 2 February 2016).

Higley, J., Kullberg, J. and Pakulski, J. (1996) The persistence of postcommunist elites, Journal of Democracy 7 (2), 133-47. doi: 10.1353/jod.1996.0027

Hoare, A., and Johnston, R. (2011) Widening participation through admissions policy - a British case study of school and university performance, Studies in Higher Education 36 (1), 21-41. doi: 10.1080/03075070903414297

Hollander, S. C., Rassuli,K. M., Jones, D. G. B. and Dix, L. F. 2005. Periodization in Marketing History, Journal of Macromarketing, 25 (1), 32-41

Huckfeldt R. and Kohfeld, C. W. (1989): Race and the decline of class in American politics, University of Illinois Press, Chicago.

Hyde, M., and A. Hyde. (2014) Going to University Abroad: A Guide to Studying Outside the UK. (Abingdon, Routledge).

Janis, I. L. (1982). Groupthink: Psychological Studies of Policy Decisions and Fiascoes. (New York, NY, Houghton Mifflin).

James, Simon (1999) British Cabinet Government. $2^{\text {nd }}$ ed .London Taylor \& Francis.

Keating, M. and Cairney, P. (2006) A new elite? Politicians and civil servants in Scotland after devolution, Parliamentary Affairs, 59 (1), 43-59.

Kennedy, M., and Power, M. J. (2010) "The Smokescreen of meritocracy": Elite Education in Ireland and the reproduction of class privilege. Journal for Critical Education Policy Studies, 8(2), 223- 48.

Lane. D. (ed.) (2007): The transformations of State Socialism: system change, capitalism or something else?, Palgrave McMillan, London.

Lane, D. (2011) Elites and Classes in the Transformation of State Socialism. (New Brunswick, NJ, Transaction Publishers).

Lasswell, H. D., Learner, D. and Rothwell, C. E. (1952) The comparative study of elites: An introduction and bibliography. Stanford: Stanford University Press.

Lasswell, H. D., and Kaplan, A. (1950). Power and Society. New Haven: Yale University Press.. 
This is the final submitted version of the paper the published version of which is Feeney, S., Hogan, J. \& O'Rourke, B. K. (2017) Elite formation in the higher education systems of Ireland and the UK: Measuring, comparing and decomposing longitudinal patterns of cabinet members. British Journal of Education Research. Available on early view at: http://onlinelibrary.wiley.com/doi/10.1002/ber.3284/full

Lee, J. J. (1989) Ireland, 1912-1985: Politics and Society (Cambridge, Cambridge University Press).

Lieberman, E. S. (2001) Causal Inference in Historical Institutional Analysis: A Specification of Periodization Strategies, Comparative Political Studies, 34(9), 1011-35. doi: 10.1177/0010414001034009003

Lijphart, A. (1999) Patterns of Democracy: Government Forms and Performance in Thirtysix Countries, (New Haven, CT, Yale University Press).

Mahoney, J., and Rueschemeyer, D. (2003) Comparative Historical Analysis: Achievements and Agendas, in J. Mahoney and D. Rueschemeyer (Eds), Comparative Historical Analysis in the Social Sciences. (Cambridge, Cambridge University Press).

Marsh, D., Richards, D., \& Smith, M. J. (2000). Re-Assessing the Role of Departmental Cabinet Ministers. Public Administration, 78(2), 305-326

Marx, K., and Engels, F. (1906) The Communist Manifesto (F. Engels, Trans.) (Chicago, IL, Charles H. Kerr and Company).

Mills, C. W. (1958) The Causes of World War Three (London, Secker \& Warburg).

Mosca, G. (1939) The Ruling Class (H.D. Kahn, Trans.). (New York, NY, McGraw-Hill). O'Rourke, B. K., Hogan, J. and Donnelly, P. F. (2015) Developing an elite formation index for comparative elite studies: The case of the schooling of Irish and UK cabinet ministers, Politics 35 (1), 3-18. doi: 10.1111/1467-9256.12071

O'Toole, F. (2009) Ship of Fools: How Stupidity and Corruption Sank the Celtic Tiger. (New York, NY, Faber \& Faber).

Pareto, V. (1935) The Mind and Society (A. Bongiorno and A. Livingston, Trans.). (London, Jonathan Cape).

Parry, G. (2005) Political Elites $2^{\text {nd }}$ ed (Colchester, ECPR Press).

Podolny, J. M. and Barron, J. N. (1997). Relationships and resources: social networks and mobility in th eworkplace. American Socilogical Review, 16(1), 18-21.

Potts, R. (2016) "Universities to increase tuition fees above $£ 9,000$ for current students." Independent, July 21. Available online at: http://www.independent.co.uk/student/studentlife/finances/university-tuition-fees-uk-rise-9000-cost-how-much-higher-education-coursesa7148956.html.

Power, M., O’Flynn, M., Courtois, A., \& Kennedy, M. (2013). Neoliberal Capitalism and Education in Ireland. In Hill, Dave (Ed.), Immiseration Capitalism, Activism and Education: Resistance, Revolt and Revenge.(pp. 41-59). (Brighton, Institute for Education Policy Studies). 
This is the final submitted version of the paper the published version of which is Feeney, S., Hogan, J. \& O'Rourke, B. K. (2017) Elite formation in the higher education systems of Ireland and the UK: Measuring, comparing and decomposing longitudinal patterns of cabinet members. British Journal of Education Research. Available on early view at: http://onlinelibrary.wiley.com/doi/10.1002/beri.3284/full

Richards, D., and Smith, M. (2007) Central control and policy implementation in the UK: A case study of the Prime Minister's Delivery Unit, Journal of Comparative Policy Analysis 8 (4), 325-345. doi: 10.1080/13876980600971151

Riddell, P., Gruhn, Z., \& Carolan, L. (2011). The challenge of being a minister: Defining and developing ministerial effectiveness (London, Institute for Government).

Sacks, P, (2007). Tearing down the gates: Confronting the Class Divide in American Education. (Berkeley, CA, University of California Press.

Scott, J. (ed.). (1990) The sociology of elites. Vol. 1: The study of elites. (Aldershot, Edward Elgar Publishing Ltd).

Soares, J. A. (2007) The Power of Privilege: Yale and America's Elite College. (Stanford, CA, Stanford University Press).

Sutton Trust (2012). The educational backgrounds of the nation's leading people. London: Sutton Trust.

Van Zanten. A. (2010) The Sociology of Elite Education in M. W. Apple, S. J. Ball, and L. A. Gandin (Eds), The Routledge International Handbook of the Sociology of Education. (Abingdon, Routledge).

Van Zanten, A. and S. J. Ball, eds. (2015). Elites, Privilege and Excellence: The National and Global Redefinition of Educational Advantage. World Yearbook of Education Series. (Abingdon: Routledge).

Vergara, L. G. (2013) Elites, political elites and social change in modern societies1, Revista de Sociología (28) pp. 31-49

Verzichelli, L., and Edinger, M. (2005). A Critical Juncture? The 2004 European Elections and the Making of a Supranational Elite. Journal of Legislative Studies, 11(2): 254-274.

Wakeford, F., and J. Wakeford. (1974) Universities and the study of elites, in P. Stanworth and A. Giddens (Eds). Elites and Power in British Society (Cambridge, Cambridge University Press).

Wakeling, P. and M. Savage (2015) Elite Universities, Elite Schooling and Reproduction in Britain, in A. Van Zanten, S. J. Ball, and Brigitte Darchy-Koechlin.(Eds), Elites, Privilege and Excellence: The National and Global Redefinition of Educational Advantage (Abingdon, Routledge).

Weidman, J. C., Twae, D. J., and Stein, E. L. (2001). Socilaization of graduate and professions students in higher education: a perilous passage (ASHE-ERIC, Higher Education Report 28(3)). Washington: Association for the Study of Higher Education. 
This is the final submitted version of the paper the published version of which is Feeney, S., Hogan, J. \& O'Rourke, B. K. (2017) Elite formation in the higher education systems of Ireland and the UK: Measuring, comparing and decomposing longitudinal patterns of cabinet members. British Journal of Education Research. Available on early view at: http://onlinelibrary.wiley.com/doi/10.1002/beri.3284/full 